\title{
Blasts 2-4 Percent of Peripheral Blood White Cells
}

National Cancer Institute

\section{Source}

National Cancer Institute. Blasts 2-4 Percent of Peripheral Blood White Cells. NCI

Thesaurus. Code C155288.

A semi-quantitative microscopic finding indicating that between 2 and 4 percent of the nucleated cells in a peripheral leukocyte sample are immature mononuclear cells. 